\title{
Implications of De-Industrialization for Poverty and Income-Inequality in Pakistan
}

\author{
Bushra Yasmin * \\ Wajeeha Qamar**
}

Abstract: This study endeavors to identify the dynamic link among growth, inequality and poverty, instigated from deindustrialization, in Pakistan over the time period 1970-2013. The Reduced-form Vector Autoregressive Model (VAR) is applied to estimate the empirical model. According to the results, trade openness has declining (mounting) impact on poverty (income inequality) over the specified time period. Moreover, the industrial sector share in GDP has appeared as a major contributing factor in tackling income inequality and poverty. This implies that the deindustrialization, as an emergent of trade liberalization, neutralizes the policy effect for income distribution and poverty in Pakistan. Besides, the Kuznet's hypothesis has been proved to be true in case of Pakistan where GDP growth has led to increase in the income inequality. The role of industrial sector growth in tackling poverty and income inequality has emerged as vital but the move towards rapid trade liberalization has placed this sector in more competitive position and the persistent nature of income inequality has subdued the growth effects on poverty. The results underlie very pertinent policy to focus on the sector-specific growth in order to tackle the welfare issues. And a cautious move towards trade liberalization is also suggested.

Keywords: Inequality, Poverty, Globalization

JEL Classification: O15; I32; F62

\section{Introduction}

Growth, poverty and inequality nexus has long been attracting the attention of the policy researchers. The economic growth has been considered a necessary condition for poverty alleviation. The latest support to the crucial role of economic growth for

\footnotetext{
${ }^{*}$ Bushra Yasmin is at Fatima Jinnah Women University, Department of Economics, Rawalpindi.

** Wajeeha Qamar is M. Phil student at Fatima Jinnah Women University, Department of Economics, Rawalpindi.
} 
poverty alleviation for developing countries given by Fosu (2010) concludes that 'on average, income growth has been the major driving force behind both the decline and increase in poverty'. However, this average dominant-growth theory varies across regions and countries and is inclined to the retention of income inequality. The income inequality is playing a major role in explaining poverty behavior and the equal income distribution has been regarded as a sufficient condition in the literature in this regards. The relatively favorable income distribution can make 'growth' the main driver for poverty reduction. This implies that GDP growth can lead towards poverty alleviation provided that equal income distribution holds in the economy. Precisely, the unequal distribution of income has been regarded a serious impediment in the way of effective poverty alleviation (Ravallion, 1997).

However, the cross-country evidence state that the countries with stable inequalities are not significantly making difference towards poverty (Deininger and Squire, 1998). In particular, the negative growth effect of inequality on the poverty is observed to be more pronounced where measure of inequality i.e., Gini coefficient was a bit low and ranges between 5 to 20 percentage points (Kanbur and Nora, 1999).

Regarding the pass through from growth to inequality, the strand of research is based on the seminal Kuznet hypothesis (1955), postulating an increase in income inequality during early periods of growth and the reduction during subsequent periods. Nonetheless, recent evidence portrays mixed evidence in this regards and it is not easy to say that whether growth effect on poverty dominates with the perception of no trade-off between growth and poverty or it is inequality that has been more important to tackle the poverty. As postulated by White and Anderson (2001), in a quarter of studies inequality has appeared as more important determinant of poverty than growth. But the growth effect of inequality dominates in the countries where major focus of the policies was economic growth.

In short, the economic growth can be achieved with rising living standards whereas poverty reduction and income equality are significant requirements for improvement in living standards in an economy. Therefore, reducing poverty and improving income distribution are the key objectives of policy makers concerned with social welfare. However, the simultaneous achievement of both the objectives proved difficult to accomplish by acknowledging the fact that there are different conceptions of poverty and income inequality (Beteille (2003)). Despite the empirical evidences on the poverty, inequality and growth nexus, the development policies mainly focus on poverty reduction with little attention to income equality with the general perception i.e., poverty reduction ultimately leads to income equality.

Notwithstanding, this is pertinent to mention that even the evidence on the growth, inequality and poverty nexus remains partial if not controlled for other intriguing variables. The studies incorporating the role of trade liberalization and the major factors modeling the poverty and income inequality equations came up with the better captivation of the issue under discussion. In that regards, the role 
of industrial sector downfall is expected to be critical, specifically in the case of Pakistan. As the industrial sector has remained one of the major labor absorbing sectors, its growth has remained stagnant for the last two decades. The large scale manufacturing and the construction industries have been the second major source of employment in Pakistan after the agriculture sector, accounting for more than 20 percent of employed labor force (Pakistan, Govt. of (2013-14)). But the growth rate of manufacturing employment that increased radically for the initial two decades sharply declined later and then became stagnant. For Pakistan, the phenomena of industrial downfall, referred as pre-mature deindustrialization whether in the form of a stagnant industrial sector or loss in the labor inclusion, is considered as the outcome of a number of factors including energy crises, poor law and order situation, trade liberalization, structural weaknesses and the institutional framework (Yasmin and Qamar, 2013).

More intrinsically, the wave of neo-liberalism stands out in this phenomenon. The neo-liberal argument supports an equal distribution of income between the entire world's people over the time. Dollar and Kraay (2002) emphasized, "the current wave of globalization, which started around 1980, has actually promoted economic inequality and reduced poverty". According to Wade (2004), empirical evidence from the world confirms neo-liberal economic theory-more open economies are more prosperous. According to advocates of neoliberal model, the export-led reforms foster the economic growth on the basis of increased labor demand and capital use. However, the implications of trade liberalization for developing countries like Pakistan may have been following the other path. Neither the demand for labor grew at the expected rate during the period of globalization nor did the level of poverty and inequality reflect the declining trends. The entry of China and other countries has become a challenge for Pakistan in gaining higher comparative advantage specifically in the manufacturing sector. Conclusively, the link between trade liberalization and deindustrialization and its ultimate role in poverty and income inequality are worth investigation. According to Bogliaccini (2013), the trade-lead deindustrialization and its role in dealing with poverty and income inequality has worked out for the Latin American countries. The author stated that,

"...the process of economic integration to the global market has produced an increase in inequality through the destruction of formal employment in Latin America” (pp: 79)."

Keeping in view the above arguments, it is expected that trade liberalization can play a critical role in determining the current scenario of poverty and income inequality through deindustrialization in Pakistan. In the context of channel discussed above, this study endeavors to identify the dynamic link among growth, inequality and poverty controlling for the deindustrialization and trade liberalization in Pakistan over the time period 1970-2013. The Recursive Vector Autoregressive Model 
(VAR) is applied to get the empirical evidence in this regards. The recursive VAR allows the error terms in each regression equation to be uncorrelated with the error in the preceding equation. The dynamic property of VAR is expressed through the lagged values of the variables describing the movements in endogenous variables.

The rest of the paper is organized as follows. The section next provides the review of literature followed by overview of the economy from deindustrialization, poverty and inequality perspectives. Section four provides the methodology and section five reports and interprets the empirical results. Last section concludes the study with some policy implications.

\section{Poverty, Inequality and Deindustrialization: A Critical Review}

A wide literature is available on the growth, inequality and poverty nexus. However, there is dearth of literature on linking this nexus with deindustrialization and trade liberalization.

\section{Growth, Inequality and Poverty}

Initially the focus of literature was on growth and poverty linkage that ultimately challenged by the intervening role of income distribution into this link. Different channels have been empirically investigated in this regards which are comprised of the direct effect of inequality on poverty and indirect effect through growth. The other link takes its route from growth to inequality. Deininger and Squire (1996), Ravallion (1997), Kanbur and Klusting (1999) and Ravallion (2001) came up with the diverse findings for the first channel. While the assessment of Kuznet curve (1955) made by a number of studies including Ahluwalia (1976), Saith (1983), Papanek (1986), Campano and Salvatore (1988) and Jha (1996). These studies tried to find out the possible trade-off between growth and inequality. Cross-country evidence by Deiniger and Squire (1998) showed a strong negative relationship between initial inequality in the asset distribution and long-term growth. They suggested that the inequality reduces income growth for the poor but not for the rich and a little support is found about Kuznets hypothesis. Another cross-country study by Ravallion (2001) identified the weaknesses in existing literature and provided that the data problems demand a deeper micro insight on the growth and distributional change. Accordingly, the focus of literature moved towards the findings beyond averages. However, the nexus is still under debate and no consensus has been developed so far. 


\section{Trade and Income Inequality}

The channel of trade towards income distribution starts from the standard model of factor price equalization and Heckscher-Ohlin (HO) Theorem. From macro perspective the channel works out as; greater openness would increase the relative demand and the price of unskilled labor and leads to more equal distribution of wages in the low-skilled-labor abundant countries. Keeping in view the limitations imposed by unrealistic assumptions, the empirical evidence came up with diverse findings. The difference in technology adopted by developed and developing countries may yield assorted effects on the trade channel to income distribution and may deviate from what standard trade models suggest. The evidence is also supported by Berman and Machin $(2000,2004)$ for middle-income DCs in the 1980s. Overall, the findings by Wood (1994), Caldero'n and Chong (2001) and Dollar and Kraay (2004) justifies the standard HO model but Barro (2000), Ravallion (2001), Easterly (2005) and Milanovic and Squire (2005) supported positive relationship between trade and income inequality for the selected sample. ${ }^{1}$

\section{Trade and Deindustrialization}

The role of trade as a source of deindustrialization was emphasized by Sachz and Shatz (1994), Seager (1997), Alderson (1999) and Shafaeddin (2005). In the context of developed world, the expansion of trade linkages between North and South provides the justification for the contraction of industrial sector. There are two theoretical reasoning put forth for the trade lead deindustrialization in the North. Seager (1997) used the Stolper-Samuelson theorem to elaborate that the opening up of trade with unskilled-labor abundance will reduce the relative price of unskilled-intensive manufacturing goods in North. Due to reduction in the production of unskilled manufacturing goods, the labor will shift to the non-tradable sector, hence creating deindustrialization in North. According to the dynamics of Stolper-Samuelson theorem, deindustrialization is a result of difference in the skill requirement of production in the import competing and export sector.

Cornwall (1980) analyzed the trends in manufacturing and services sector share for the developed economies of OECD. It was suggested that the employment and output share of manufacturing sector in these countries was initially high but it declined as the per capita income increased. It was observed that the reduction in the manufacturing share can be attributed to excessive allocation of resources to services sector, reduced demand of manufactured products and the higher productivity of the manufacturing sector. But for the developing countries, deindustrialization has not been the result of increased per capita income or the successful completion of the structural transformation process. Rather, the reduction in share of industrial sector has been attributed to uncompetitive industrial exports, liberalization reforms and 
poor macroeconomic situations and industrial policies (Palma (2008) and Bogliaccini (2013)).

Deindustrialization in Latin America and Africa has been identified as the outcome of liberalization reforms undertaken by the Structural Adjustment Programs (SAPs), International Monetary Fund (IMF). Trade liberalization lead to the destruction of inefficient industries because these industries were not able to compete in the world economy and the outcome was an efficient industrial sector in the developing economies (World Bank (1994)). However, Shafaeddin (2005) counter-argument says that some inefficient industries were more likely to become gradually efficient if trade liberalization was undertaken selectively and gradually, specifically in the case of East Asian countries. Therefore, the implementation of trade and financial liberalization without due attention towards its channels and internal rigidities by the developing countries resulted in the stiffer foreign competition.

\section{Implications of Deindustrialization}

The specific focus of globalization in targeting poverty and income inequality was proposed to be a positive contribution by neo-liberal approach, started around 1980s. Wade (2004) pointed out that the countries like China, India and the rest of East Asia has experienced fast economic growth and fall in poverty rate while the Latin American countries stay stagnant. The study related the role of globalization with "mutual benefit" than "conflicting interest". Lee (2005) tested the effect of globalization and deindustrialization on the labor market through its effect on unions of Economic Co-operation and Development (OECD) countries for 1962-1997. Using the Feasible Generalized Least Square (FGLS) estimation technique, the results indicate that the international labor migration and deindustrialization in the selected OECD countries are reducing the trend of unionization in these economies. This is because international migration has increased the heterogeneity of and competition among workforces within a country, thereby making it more difficult for trade unions to recruit union members. Similarly, with the reduction in employment in industry, the availability of labor to be unionized reduces and hence decreases the net union density. Similarly, Doussard et. al. (2009) supported the argument of increased inequality in Chicago due to restructuring of the economy through deindustrialization. However, the findings are not supplemented with any regression tool. Meschi and Vivarelli (2009) testified the phenomena on within-country income inequality for 65 developing countries over the 1980-1999 periods. The findings suggested that trade with high income countries worsens income distribution in developing countries through both the exports and imports. They supported the hypothesis of technological differentials and skill biased nature of new technologies leading towards income inequality across the world. Bogliaccini (2013) provided the evidence for Middle-income Latin American Countries in this regards and empirically proved that trade liberalization 
lead towards the deindustrialization that produced an increase in inequality through destruction of formal employment.

This completes the literature survey available so far on the issue.

\section{Poverty and Inequality in Pakistan: A Retrospect}

Historically, the focus of economic policies in Pakistan has been placed on reducing poverty through higher economic growth. Before 2000s, the direct policy intervention for poverty reduction was limited and it gained attention momentously since the adoption of the Millennium Development Goals (2000). According to MDGs the eradication of poverty and hunger is a first step towards justice and a progressive society. According to the MDG-1, the proportion of people living below national poverty line will be halved till 2015 and absolute poverty will be reduced to 13 percent. According to Economic Survey (2013-14), the high growth has been leading towards reduction in poverty, lending support to poverty-growth nexus and poverty headcount was at 12.4 percent in 2010-11. But, the inequality channel is missing in these ambitious correlates and it is asserted that the poverty rate is much more than announced figures and the income disparity is much more than projected level. One of the intervening reasons is the contraction of industrial sector growth, resulting in lack of jobs and creating inequality among masses.

Looking into past, the poverty trends persisted in first two decades with noticeable increase. Although urban poverty declined in 1960s, there was a considerable rise in rural poverty resulting in an overall increase in poverty during this decade. The prevalence of inequality in this decade is mostly associated with the green revolution that was highly biased towards elite farming class. The affordability of advanced technology was a key factor which allowed large landowners to reap the potential benefits of Green Revolution, with which the poor farmers were deprived off. Overall economic growth was increased but with rising poverty and inequality trends.

The following decade of 1970 s witnessed the improvement in poverty and income distribution despite low economic growth. The headcount percentage reduced to 30.68 from 46.53 percent in 1979 according to official figures (Pakistan, Govt. of (1999)). However, income inequality remained stagnated (UNDP (1999)). The policy of 'nationalization' from 1972-77 was fundamental in providing employment opportunities as public sector employment and share of social sectors in development plans increased considerably. Additionally, the land reforms implemented in 1972 may have had an impact on poverty reduction as agricultural land and credit was directed towards small farmers. Self-employment and small-scale sectors were encouraged through credit dispersion to small businesses (Zaidi (2005)). The initiation of 'remittance economy' also had significant impact on poverty reduction which continued to the end of 1980s. During 1972-77, \$ 1.4 billion were earned 
by overseas Pakistani which rose to $\$ 4.2$ billion at the end of the decade (Pakistan, Govt. of (1979)).

Remittances continued to be the single biggest factor responsible for higher economic growth and reduced poverty in 1980s. During the whole decade, \$23.1 billion were remitted to Pakistan which accounted for 10 percent of GDP. Per capita income rose by 3.2 percent owing to the increased development expenditures as well as spending on social sectors. The headcount percentage reduced to 17.32 indicating sharp decline in poverty. The income distribution also improved as the GINI coefficient reduced to 0.348, although by small margin (Pakistan, Govt. of (1999)). The Five Point Program, launched in 1985 as a part of development strategy, was also a key factor in improving the situation on the poverty front. The program focused on education, health, road infrastructure and housing plans for rural sector. Such spending on rural development is said to have promoted employment and income opportunities for rural poor.

At the end of 1980s, the economy started reforms under Structural Adjustment Program (SAP), IMF which marked another era of lower growth and higher poverty and income inequality. The headcount percentage rose to $22.11 \mathrm{in} 1991$ which further rose to 32.60 in 1999 . On the other hand, income inequality increased with GINI equals to 0.407 in 1991 which further reached to 0.410 in 1999 (Pakistan, Govt. of (1999)). The drastic scenario is mainly attributed to lower GDP growth whereas real per capita income growth was estimated to be 1.3 percent for the whole decade. The development expenditures reduced from 9.3 percent in 1980 to 3 percent in 1998 and remittances declined by about 41.8 percent between 1983 and 1997. The rapid privatization lead to reduction in employment as public sector employment fell by 10 percent and 43.2 percent of workers were laid off by the private sector enterprises (Zaidi (2005)). Additionally, food subsidies cut to 22.4 percent in 1995 which was crucial for the consumption pattern of the poor along with the rise in indirect taxation. Overall, poverty reducing indicators i.e. economic growth, employment, public expenditures, remittances and subsidies had worsened over the 1990s.

Pakistan adopted Millennium Development Goals in 2000 and recognized the importance of eradicating extreme poverty and hunger for overall development. For the first time, Pakistan's Planning Commission declared an Official Poverty Line (OPL). It was decided then that the OPL for Pakistan will be estimated on a 2350 calories per adult equivalent per day. This is based on an adult equivalent intake of 2150 calories in the urban areas and 2450 calories in the rural areas (PPAF (2013)). The poverty index based on this poverty line indicates that the situation of poverty improved in the decade. The index was estimated to be 34.4 percent in 2001 which fell to 22.3 percent in 2006 and further reduced to 12.4 percent in 2011 (Planning Commission (2012)). The GINI index also shows declining trend as it was reported to be 30.6 in 2001 which declined to 24.6 in 2012 (WIID (2012)). This reduction in both poverty and income inequality is generally attributed to increased allocations to the 
social safety net programs like Benazir Income Support Program (BISP), Pakistan Poverty Alleviation Fund (PPAF), improved support prices of agriculture products that assisted in reduction of consumption based poverty head count in rural areas, enhanced varieties of crop seed resulting in better agriculture output, improvement in inflow of remittances due to better manpower export policies.

Overall, the recent trends indicate improvements in poverty and income distribution. However, there is a dire need of long term policy plans for reducing poverty and to achieve fair distribution of income in terms of better allocation of resources to the social sector combining with the social safety nets.

Turning to the industrial sector performance, specifically it has been remained stagnant over the period of time with ever declining agriculture sector share and rising share of services sector in GDP. The industrialization has long been considered as an engine of growth since the emergence of the Industrial Revolution. With reference to trade liberalization era, the industrial sector in Pakistan did not perform very well due to open competition from the neighbor countries like China and India. Pakistan followed the import substitution industrialization policy till 1970s. The process of trade liberalization started in the backdrop of SAP in 1980s. During 1990s, the major contribution in exports and imports was that of manufacturing sector but the net exports started declining since 2000. The phasing out of Multi-Fiber Agreement (MFA) in 2006 led towards further decline in the industrial sector performance due to low competitiveness. According to Human Development Centre (2010) policy brief No. 2,

"...the situation has been deteriorated further after the US removal of quotas from China in January 2009. Since 2005 net manufacturing trade has gone down significantly."

The manufacturing exports in Pakistan are characterized by low diversification, high concentration in few products, lesser integration and low technical-intensity. According to the Industrial Development Report (2009), since 1990s the share of medium and high technology exports in manufacturing trade has increased significantly in the world, indicating a reduction in the share of low-technology exports.

Figure 1 shows the trends in poverty, income inequality and the industrial sector share in GDP. The poverty measured by headcount (\%) is sourced from Jamal (2004). ${ }^{2}$ Whereas the inequality measured by Gini (\%) is extracted from the World Income Inequality Database 2012, World Institute of Development Economic Research. This can be observed that the industrial sector share in GDP has remained stagnant around $25 \%$ and has not been able to reach to a sufficient level of output. The poverty has depicted a continuous fall in 1980 till mid-1990s while the inequality has remained fluctuating. The correlates among the trends can be better portrayed with the help of regression techniques coming in subsequent sections. 
Figure 1: Poverty, Inequality and Industrial Sector Share (1970-2012)

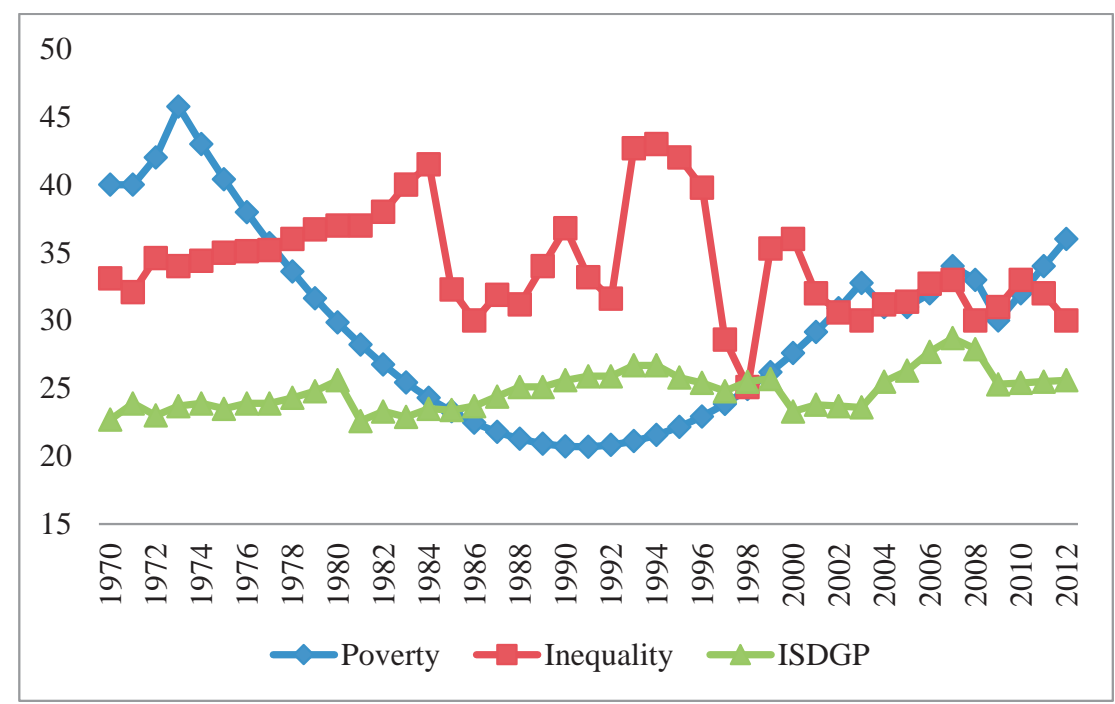

Source: Pakistan, Govt of (2013), WDI (2012) and WIID (2012)

\section{Methodology}

Vector Autoregressive Model (VAR): Theoretical Framework and Model Specification

The methodology adopted for the objective of study is Vector Autoregressive Model (VAR) that encapsulates both the causes and consequences of industrial sector's declining share in GDP of Pakistan over the time period 1970-2012. A Vector Autoregressive Model (VAR) is equivalent to a system of reduced form equations that relates each endogenous variable to lagged endogenous and exogenous variables. This framework provides systematic way to capture the rich dynamics in multiple time series. Sim (1980) provided that VAR approach is coherent and credible to the data description, forecasting and policy analysis.

Basic model of VAR is given as follows:

$$
X_{t}=A(L) X_{t-1}+U_{t}
$$

Where $\mathrm{X}_{\mathrm{t}}$ is the $5 \times 1$ vector of endogenous variables e.g. $\mathrm{X}_{\mathrm{t}}=\left[\right.$ to $_{t} i s g d p_{t} g d p c_{t}$ ie pov]. A (L) is $5 \times 5$ matrix of lag polynomials and $\mathrm{U}_{\text {, }}$ is the $5 \times 1$ vector reduced

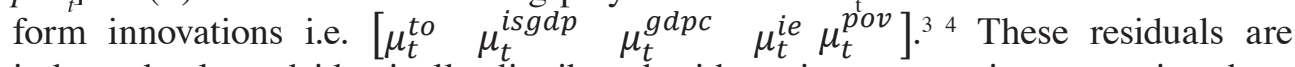
independently and identically distributed with variance, covariance matrix where $E\left(U_{t}\right)=0 ; E\left(U_{t} U_{t}^{\prime}\right)=\sum u_{t}$ 
In the above giving specification, the variable to stands for Trade Openness, isgdp for industrial sector share in GDP as measurement of Deindustrialization, $g d p c$ refers to the Per Capita Gross Domestic Product growth, ie for income inequality measured by Ginni coefficient and pov is poverty, measured by the head count ratio.

\section{Identification and Justification of Variables}

The complexity in the reduced form VAR with Choleski decomposition demands an identification procedure in order to extract meaningful implications. The identification serves to transform the correlated innovation of a reduced form into uncorrelated and theoretically meaningful structural shocks. Generally, Sim's (1980) restrictions are imposed on the contemporaneous properties of the system known as short-run restrictions. Herewith, the short-run identification scheme is performed under non-triangular restrictions that are econometrically and theoretically feasible i.e., restricted matrices are fully ranked. The model follows an order for the variables keeping in view the degree of endogeneity. The ordering places trade openness (to) at first followed by the industrial sector share in GDP (isgdp), GDP per capita growth $(g d p c)$, income inequality (ie) and the last is poverty (pov) that is treated as the most endogenous. Trade openness is treated as the least endogenous variable and so is the case for other variable's ordering scheme. This scheme of identification is considered more appropriate keeping in view the major hypothesis that, 'trade liberalization is detrimental to equality because it accelerated the deindustrialization in Pakistan'. Moreover, the globalization as tainted by several economic crises is expected to have implications for income inequality (Binatli (2012)). Herewith, the trade-off between GDP per capita and income inequality serves to test the Kuznets hypothesis (1995). Similarly, inequality is expected to affect poverty positively, significantly.

The above given identification schemes with lower triangular matrix are presented as follows:

$$
\left[\begin{array}{ccccc}
\alpha_{11} & 0 & 0 & 0 & 0 \\
\alpha_{21} & \alpha_{22} & 0 & 0 & 0 \\
\alpha_{31} & \alpha_{32} & \alpha_{33} & 0 & 0 \\
\alpha_{41} & \alpha_{42} & \alpha_{43} & \alpha_{44} & 0 \\
\alpha_{51} & \alpha_{52} & \alpha_{53} & \alpha_{54} & \alpha_{55}
\end{array}\right]\left[\begin{array}{c}
\varepsilon_{t}^{t o} \\
\varepsilon_{t}^{i s g d p} \\
\varepsilon_{t}^{g d p c} \\
\varepsilon_{t}^{i e} \\
\varepsilon_{t}^{p o v}
\end{array}\right]=\left[\begin{array}{lllll}
1 & 0 & 0 & 0 & 0 \\
0 & 1 & 0 & 0 & 0 \\
0 & 0 & 1 & 0 & 0 \\
0 & 0 & 0 & 1 & 0 \\
0 & 0 & 0 & 0 & 1
\end{array}\right]\left[\begin{array}{c}
\mu_{t}^{t o} \\
\mu_{t}^{i s g d p} \\
\mu_{t}^{g d p c} \\
\mu_{t}^{i e} \\
\mu_{t}^{p o v}
\end{array}\right]
$$

\section{Impulse Response Function and Monte-Carlo Procedure}

The next step in estimation procedure is the measurement of responses towards one standard deviation shocks to selective variables per ordering scheme. This is pertinent to mention that the IRFs are sensitive to the specific ordering conditions. In the 
case of our model there will be 120 permutations or ordering for five endogenous variables. In order to determine the sensitivity of results to various ordering, the Monte-Carlo analysis will be done that takes one hundred random draws out of total possible ordering and provides the robustness check for the one selected combination for impulse response functions based on structural decomposition.

\section{Data Description}

The measure of selected variables and summary statistics is given below.

Table 1: Description of Variables

\begin{tabular}{|c|l|c|}
\hline Variables & \multicolumn{1}{|c|}{ Definition and Source } & Mean (S.D) \\
\hline TO & $\begin{array}{l}\text { Sum of imports and exports as a percentage of GDP } \\
\text {-World Development Indicators, World Bank }\end{array}$ & 0.28 (0.054) \\
\hline IGDP & $\begin{array}{l}\text { Percentage share of Industrial sector in GDP (growth rate) } \\
\text { - Various issues of Economic Survey }\end{array}$ & $24.82(1.44)$ \\
\hline GDPC & $\begin{array}{l}\text { Growth rate of per capita GDP where per capita GDP is measured in million Rupees } \\
\text { World Development Indicators, World Bank }\end{array}$ & 2.17 (0.61) \\
\hline IE & $\begin{array}{l}\text { GINI coefficient is used as a measure of income inequality. It is calculated as the mean } \\
\text { of the difference between every possible pair of individuals, divided by the mean size. } \\
\text { It lies between o and 100 because the coefficient is usually expressed in percentage } \\
\text { (UNDP (2012)) } \\
\bullet \text { World Income Inequality Database 2012 of World Institute of Development } \\
\text { Economic Research }\end{array}$ & 34.18 (3.94) \\
\hline POV & $\begin{array}{l}\text { Poverty is measured by the population below poverty line headcount Ratio } \\
\bullet \text { Jamal (2004), Various issues of Economic Survey (2013-14), and World Development } \\
\text { Indicators, World Bank }\end{array}$ & 26.61 (8.23) \\
\hline
\end{tabular}

Source: Pakistan, Govt of (2013), WDI (2012) and WIID (2012)

\section{Results and Discussion}

The results for the stationarity of variables are reported in Table 1. As the traditional Augmented Dickey Fuller and Phillip-Peron tests are not valid in the presence of structural instability of the model, the Clemento-Montanes-Reyes (1998) test of innovative outlier with single mean shift is applied for stationarity check. 
Table 2: Clemento-Montanes-Reyes Unit Root Test Innovative Outlier

\begin{tabular}{|c|c|c|c|c|}
\hline \multirow{2}{*}{ Variables } & \multicolumn{2}{|c|}{ Level } & \multicolumn{2}{|c|}{ Difference } \\
\hline & rho & Break (year) & rho & Break (year) \\
\hline TO & -3.652 & 1992 & $-7.120 * *$ & 1975 \\
\hline IGDP & -3.379 & 2002 & $-7.242^{* *}$ & 2006 \\
\hline GDPC & -3.720 & 1979 & $-8.997 * *$ & 2004 \\
\hline IE & -4.077 & 1995 & $-7.132^{* *}$ & 1996 \\
\hline POV & -2.440 & 2009 & $-4.430 * *$ & 1989 \\
\hline
\end{tabular}

Note: 1) Critical value at $5 \%$ level of significance is -4.270 .

2) $* *$ denotes the rejection of null hypothesis at $5 \%$ level of significance.

The results reported in Table 2 indicate that all variables in the model are integrated of order one i.e. I (1). The lag length selection according to Akaike and Schwarz information criteria is selected at one.

\section{Reduced-form VAR Results}

Table 3 reports the results for reduced-form VAR estimates where the coefficients show the effect of trade openness on industrial sector share in GDP, GDP per capita growth rate, income inequality and poverty denoted by $\mathrm{C}(1), \mathrm{C}(2), \mathrm{C}(3)$ and $\mathrm{C}(4)$, respectively. ${ }^{3}$ Similarly the coefficients against C (5), C (6) and C (7) depict the effect of industrial sector share in GDP on Gross Domestic Product per capita growth, income inequality and poverty. The rest of coefficients $\mathrm{C}(8), \mathrm{C}(9)$ and $\mathrm{C}$ (10) measure the effect of GDP per capita growth rate on income inequality and poverty and the effect of income inequality on poverty, respectively.

Table 3: Vector Autoregressive Results

\begin{tabular}{|c|c|c|}
\hline & Coefficients & Standard Error \\
\hline $\mathrm{C}(1)$ & $-2.509^{*}$ & 0.156 \\
\hline $\mathrm{C}(2)$ & 0.099 & 0.423 \\
\hline $\mathrm{C}(3)$ & $16.26^{*}$ & 0.422 \\
\hline $\mathrm{C}(4)$ & $-4.64^{*}$ & 2.574 \\
\hline $\mathrm{C}(5)$ & -0.016 & 0.156 \\
\hline $\mathrm{C}(6)$ & $-0.553^{*}$ & 0.156 \\
\hline $\mathrm{C}(7)$ & -0.338 & 0.178 \\
\hline $\mathrm{C}(8)$ & $11.54^{*}$ & 0.156 \\
\hline $\mathrm{C}(9)$ & $2.81^{*}$ & 1.809 \\
\hline $\mathrm{C}(10)$ & -0.023 & 0.156 \\
\hline$\chi^{2}$ - statistic & 716.12 & \\
\hline
\end{tabular}

Note: 1$) *$ indicates the significance at $1 \%$ level of significance.

2) p-value in parenthesis of Chi-square stat. 
Overall, the results are satisfactory and are in line with the theoretical expectations. The empirical findings support the hypothesis of negative implications of trade openness for the industrial sector share in GDP (isgdp) reflected in C (1) implying that the trade liberalization has pursued the deindustrialization in Pakistan. The coefficient C (2) measuring the effect of trade openness on per capita GDP growth rate $(g d p c)$ bears positive sign however it appeared as insignificant. The findings are in line with Bogliaccini (2013) for the Latin American countries and do not support the neo-liberal perspective (more open the economy more will be the growth) in the case of Pakistan. The justification of such findings relies on the perception of industry competitiveness. The comparative advantage in industrial sector has been falling in Pakistan due to stiffer competition from China and India for their quality of products. The figures show that contribution of services sector has been increasing relative to the industrial sector share and a ratio of 20:58 is observed in this regards (Pakistan, Govt. of 2013-14). More specifically, the trade liberalization has lead to the process of formal employment contraction due to its negative impact on industrial sector share and due to inability of industrial sector to compete globally as also put forth by Brady, Kaya and Gereffi (2011).

Turning to the implications of trade openness for inequality and poverty, this is evident that the trade openness has increased (decreased) the income inequality (poverty). The findings of our study do not confirm the factor-price equalization theorem that the free and competitive trade will make factor prices converge along with traded output prices with the perception of equitable income distribution. Relaxing the assumption of identical technologies across the countries, the increasing exposure to international market through trade liberalization is expected to foster the process of technological diffusion. That might be highly biased towards skilled labor and their premium that ultimately lead to the increase in inequality. The findings of our study are supporting the empirical evidence for developing countries provided by Meschi and Vivarelli (2008). The results portrays that a $1 \%$ increase in trade liberalization brings about $16 \%(4 \%)$ increase (decrease) in the income inequality (poverty). According to the findings, overall trade liberalization can lead towards poverty reduction but the policy actions ignoring the component of income distribution may be misleading. Hereafter, the impact of income inequality on poverty appeared as insignificant.

Regarding the role of industrial sector share in tackling the issues of income inequality and poverty, the findings says that deindustrialization has intensified both the issues. The results indicate that $1 \%$ increase in industrial sector share can lead towards decline in inequality and poverty by $0.55 \%(0.33 \%)$. Hence, the overall channel of effect came out from the results reflects that trade-led deindustrialization is harming the economy from poverty and inequality concern whereas inequality, in itself, has had remained partial towards poverty (result for $\mathrm{C}(10)$ ).

The corresponding results highlight the importance of direct policy measures regarding the fair income distribution similar to the actions taken up to tackle the pov- 
erty reduction. The large scale industries have always been a source of employment generation in Pakistan. This in turn can support the labor class by tackling poverty issues. But the shifting of labor to informal sector due to deindustrialization makes the situation for poor more vulnerable. The findings are in line with Bogliaccini (2013) that the trade reforms in Latina American countries are detrimental to equality because it accelerated deindustrialization. The justification put forward in this regard is that trade liberalization tends towards formal employment destruction in industrial sector due to lack of competitiveness and this process of deindustrialization prop up the inequality by destroying protected employment and enlarging the informal sector. The global market has been unable to create opportunities for specialization in the industrialization of abundant factors, or for technology-intensive production sectors. The increase in the industrial sector share has appeared with declining effect on inequality in this regards.

Finally, the effect of GDP per capita growth has appeared as positive for income inequality and poverty; however the coefficient for poverty impact of GDP (C (9)) is insignificant. The findings support the Kuznets hypothesis - the inequality increases with income in the early stage of development and only decreases in the later stages - for the case of Pakistan. The reassessment of Kuznets hypothesis by Jha (1996) also supports the inverted U curve relationship between economic development and income distribution for the developing countries. They came up with the conclusion that the data comparability problem is not severe to nullify the estimates proving this hypothesis for pooled regressions.

The future trends of selective variables can be traced out with the help of Impulse response Function (IRF) before moving towards some crucial policy suggestions.

\section{Impulse Response Function based on Structural Decomposition}

The graphs given below show the responses of selective variables to one standard deviation shocks to others variables, per ordering scheme. The IRFs are based on the structural decomposition and the Monte-Carlo findings for robustness confirm that the responses are not sensitive to the ordering. ${ }^{4}$ The basic idea behind the impulse response is that shock to one variable is not restricted to that variable only but it is transmitted to all other endogenous variables. An impulse response function traces the effect of a onetime shock to one of the innovations on current and future values of an endogenous variable.

The graph presented below shows the point estimate of the responses corresponding to the lower and the upper bands. These error bands are calculated by adding and subtracting two times standard error point estimators. 
Figure 2: Responses of Poverty to Structural one S. D. Innovations
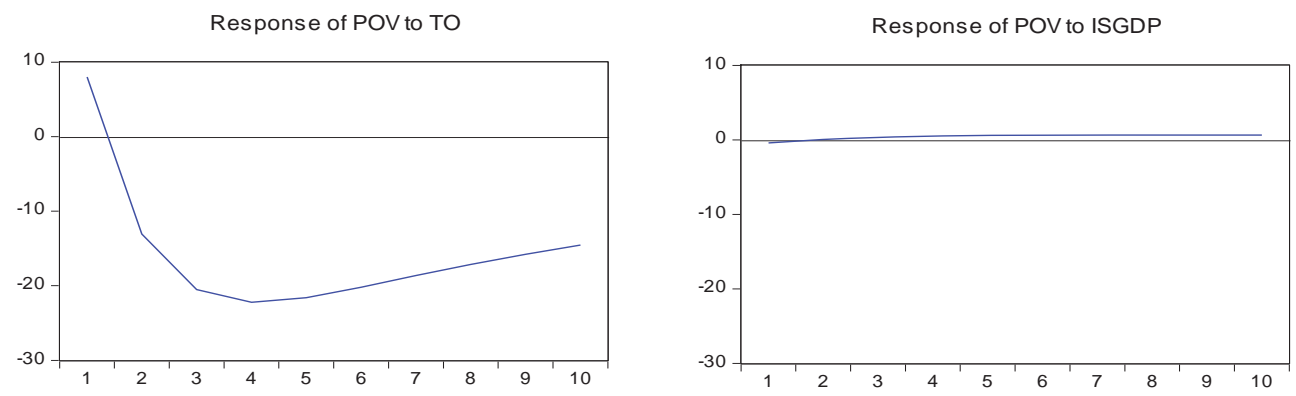

Response of POV to GDPC
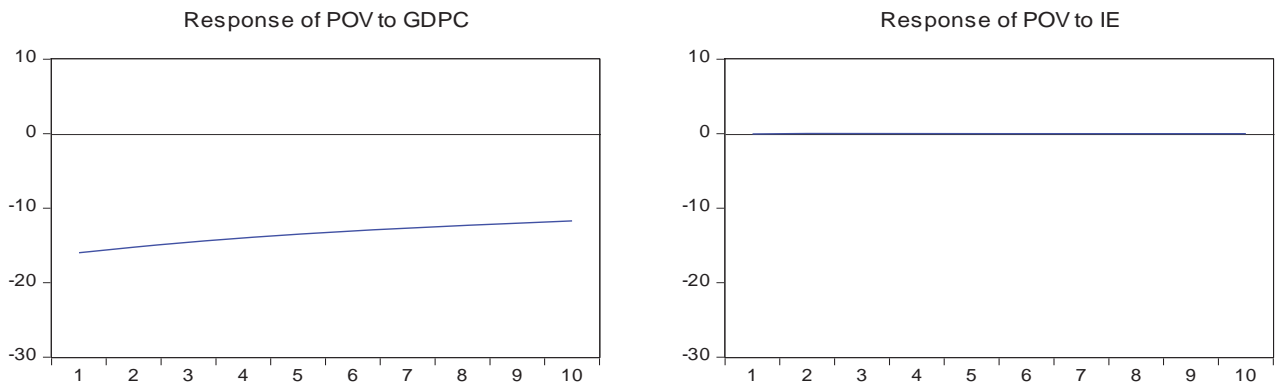

Figure 2 shows the response of poverty to one standard deviation shocks to the trade openness, industrial sector share, GDP and inequality. First panel indicates the poverty will drastically fall till the $5^{\text {th }}$ year and then it will rise steadily. The results of SVAR also yielded a negatively significant effect of trade openness on poverty. In contrast, the response of poverty to inequality and industrial sector share will remains constant over 10 years of time horizon. It implies that poverty will not respond to any expected or unexpected shocks to industrial sector share in GDP. Rather this demands smooth and direct policy actions in this regards. 
Figure 3: Responses of Income Inequality to Structural one S. D. Innovations

Response of IE to TO

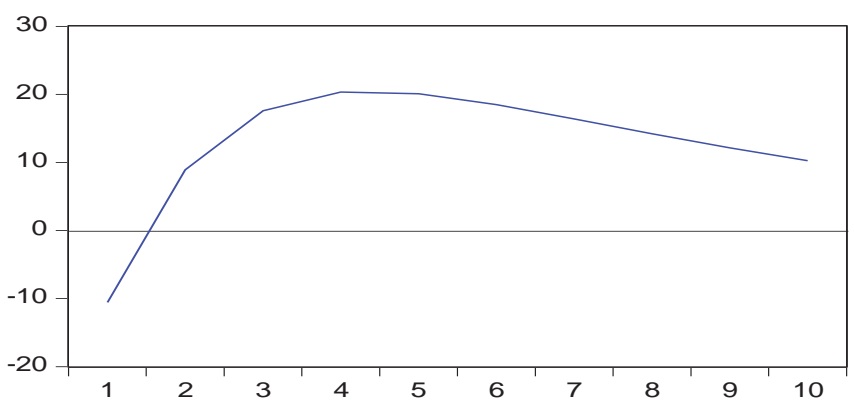

Response of IE to ISGDP

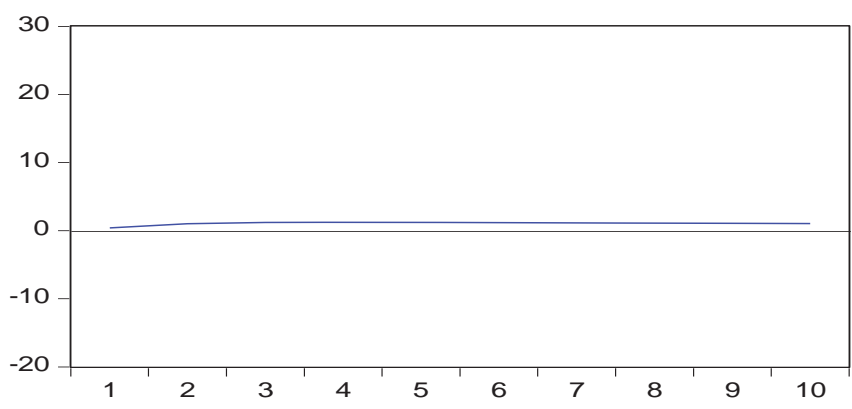

Response of IE to GDPC

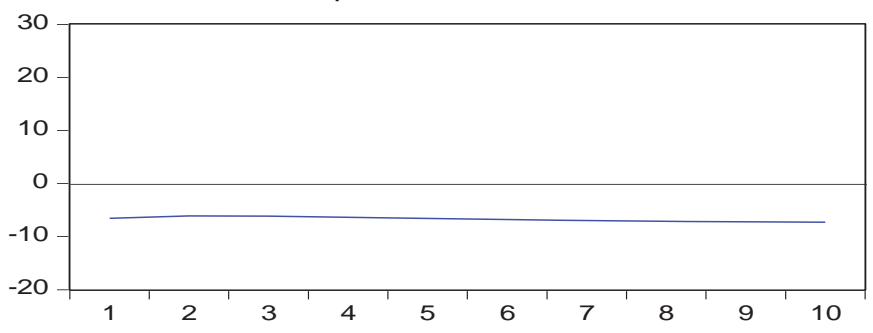

Figure 3 portrays three panels of income inequality response towards trade openness, industrial sector share and GDP growth, respectively. The response of inequality to trade was appeared as positively significant and the same will be the future trend as displayed in panel 1 . It will increase till $6^{\text {th }}$ year and then gently decline. The other two panels portray the insignificant response to shocks to industrial sector share and negative zone, respectively. 
Figure 4: Responses of GDP per capita Growth to Structural one S. D. Innovations Response of GDPC to TO

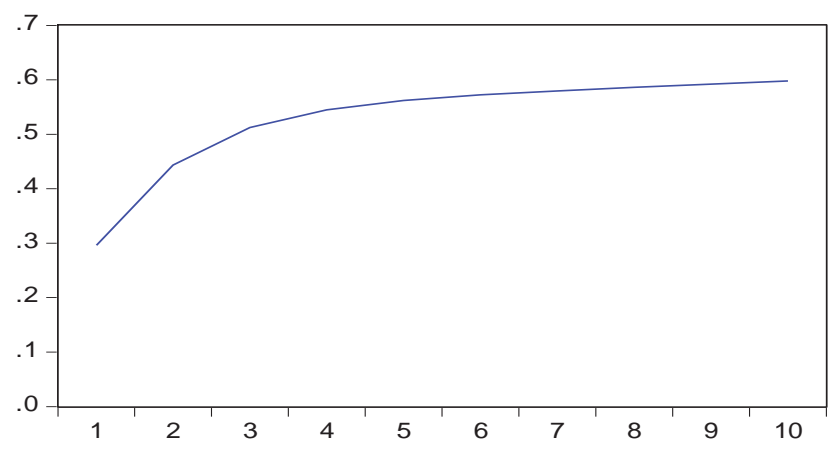

Response of GDPC to ISGDP

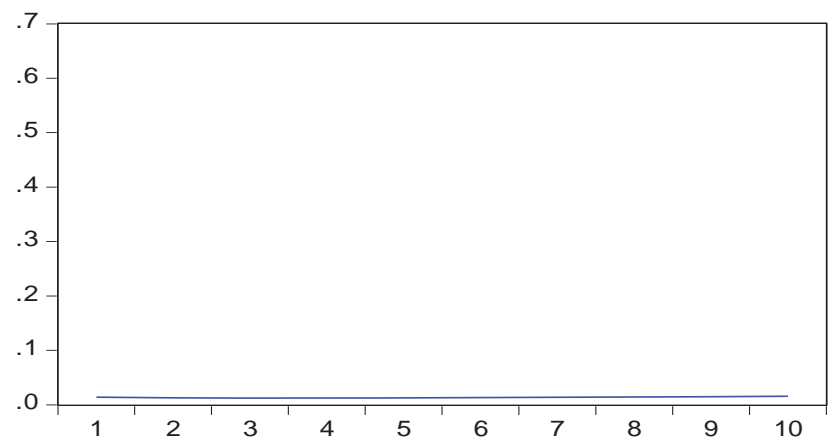

The figure above shows that GDP increase gradually to trade openness shock while it is negligible towards industrial sector share in GDP.

Figure 5: Responses of ISGDP to Structural one S. D. Innovations

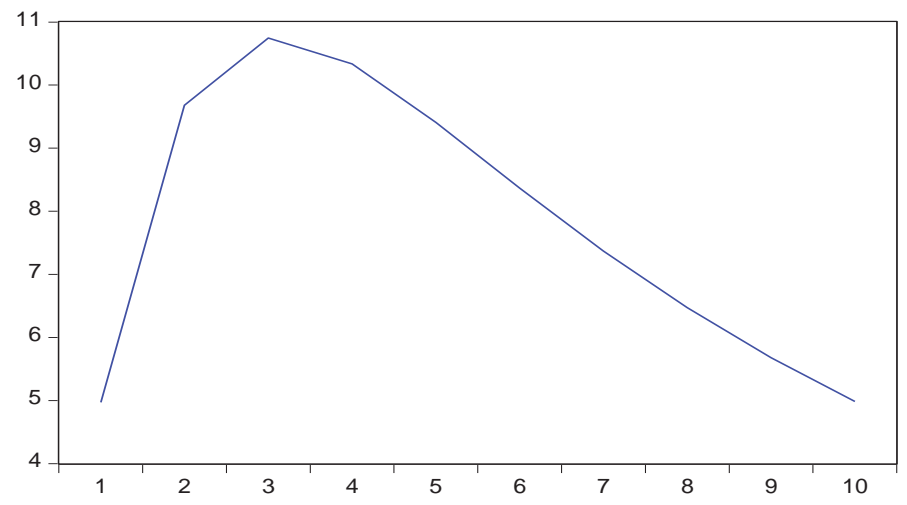


Figure 5 depicts the impulse response functions of industrial sector share in GDP (ISGDP) to one standard deviation shock to Trade Openness (TO). In response to trade openness shock, the ISGDP will rise drastically over a certain horizon and then falls smoothly. The response of industrial sector share to one standard deviation shock to trade openness shock is statistically negatively significant as appeared in results of SVAR. However, the findings of Impulse response function shows it will be positive till the next $3^{\text {rd }}$ year of predicted time horizon after that it will fall. Impulse response function indicates that trade openness will boost the industrial output only for four years.

\section{Conclusions and Policy Recommendations}

The study endeavored to find out the possible link of the crucial nexus of growth, poverty and income inequality with the trade liberalization and deindustrialization in Pakistan over the time period of 1970-2012. The Structural Vector Autoregressive (SVAR) model was applied through ordering scheme of the variables for their degree of endogeneity. The results confirm the hypothesis of trade-lead deindustrialization in Pakistan. Moreover, the results highlight the vital role of industrial sector in tackling poverty and inequality issues. The growth inequality relationship appeared to be confirming Kuznets hypothesis for inverted U type relationship.

The results pertaining to the role of industrial sector offer some important policy suggestions. First, the trade liberalization is needed to be pursued cautiously and keeping in view the relative position of the selective sector for which liberalization is being made. In order to promote industrial sector performance, the export diversification should be focused that will also enable the sector to compete globally. Secondly, the inequality and poverty issues can be resolved by promoting the industrial sector's share in GDP that has been remained sluggish for the decades. Finally, the economy of Pakistan has been entrapped in the earlier stage of development and a big push is needed to propel the industrial sector. 


\section{Appendix}

Figure 6: Monte-Carlo Analysis
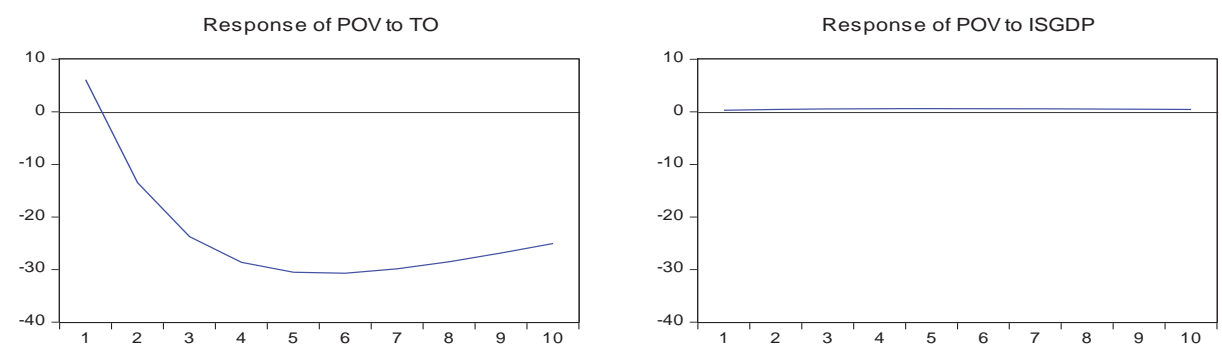

Response of POV to GDPC

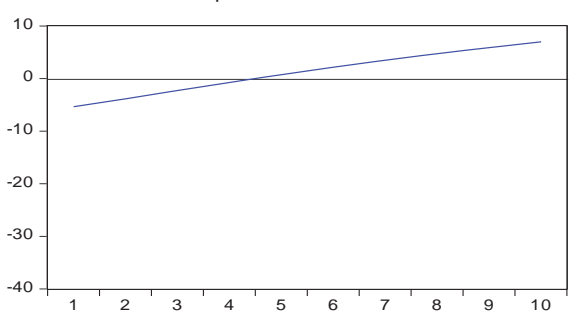

Response of POV to IE

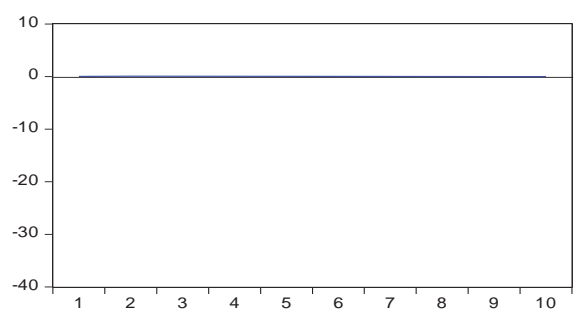

Response of IE to TO

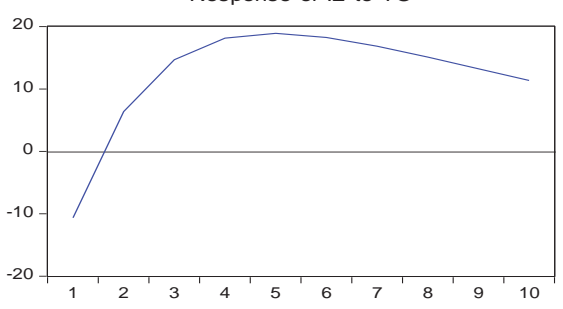

Response of GDPCGROWTH to TO

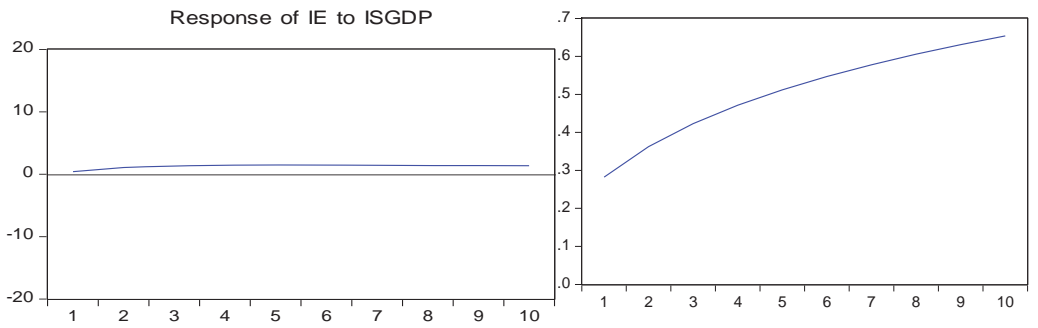




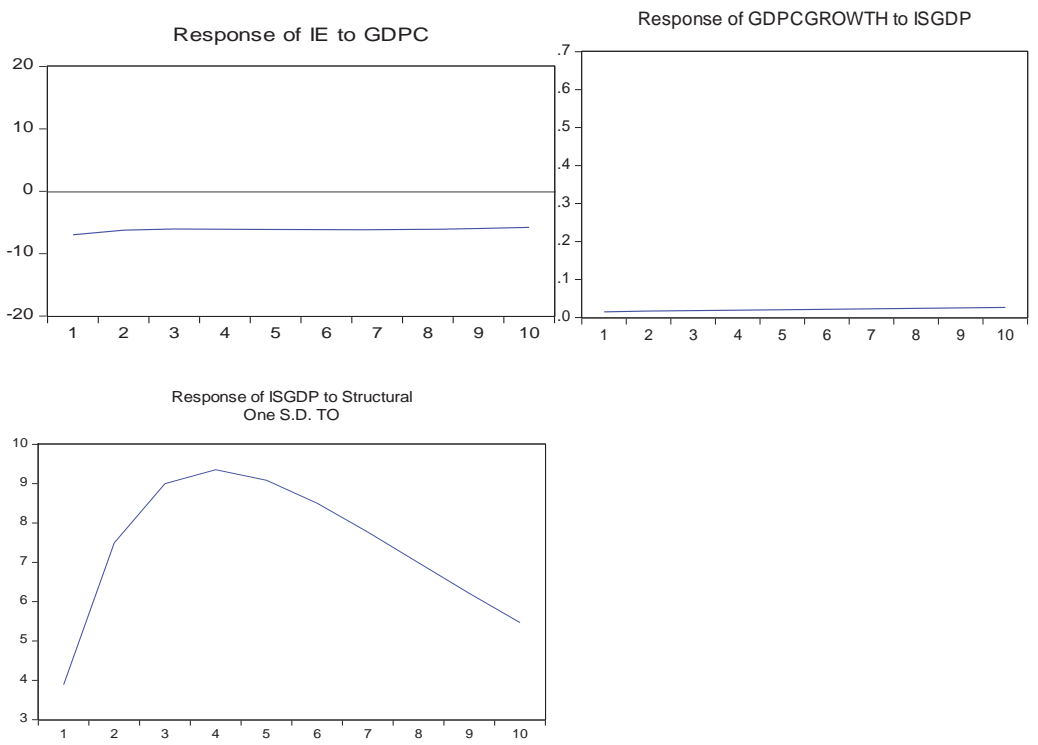

\section{REFERENCES}

Ahluwalia, M. S. (1976), "Inequality, poverty and development", Journal of Development Economics, 3: $307-342$

Alderson, Arthur S., and François, N. (1999), "Income Inequality, Development, and Dependence: A Reconsideration", American Sociological Review, 64 (4): 606-631

Amisano, G, and C. Giannini (1997), "Topics in Structural VAR Econometrics", Springer Verlag, New York

Bateille, A. (2003), "Poverty and Inequality”, Economic and Political Weekly. 38(42): 44-56.

Binatli, A. O. (2012), "Growth and Income Inequalty: A Comparative Analysis", Economic Research International, Hindawi Publishing Corporation

Barro, R. (2000). Inequality and Growth in a Panel of Countries", Journal of Economic Growth, 5, 5-32

Berman, E., and Machin, S. (2000), "Skill-biased Technology Transfer Around the World", Oxford Review of Economic Policy, 16(3), 12-22

Berman, E., and Machin, S. (2004), "Globalization, Skill-biased Technological Change and Labor Demand", in E. Lee, and M. Vivarelli (Eds.), Understanding Globalization, Employment and poverty Reduction, New York: Palgrave Macmillan, pp. 39-66.

Bogliaccini, J. (2013), "Trade Liberalization, Deindustrization and Inequality-Evidence from Middle-Income Latin American Countries", Latin American Research Review, 48(2):79-105

Brady, D., Y. Kaya and G. Gereffi (2011), "Stagnating Industrial Employment in Latin America.” Work and Occupations 38 (2):179-220

Calderón, C., and Chong, A. (2001), "External Sector and Income Inequality in Interdependent Economies using a Dynamic Panel Data Approach, Economics Letters, 71(2), 225-231

Campano, D. and Salvatore (1988), "Economic development, income inequality, and Kuznets' U-shaped hypothesis", Journal of Policy Modeling, 10 (2): 265-280 
Cornwall, J. (1980), “Modern Capitalism and Trends towards Deindustrialization”, Journal of Economic Issues, 14 (2): 275-289

Dasgupta, S. and A. Singh (2006), "Manufacturing, Services and Premature Deindustrialization in Developing Countries", World Institute for Development Economics Research, Discussion Paper 49. Finland

Deininger K. and L. Squire (1996), "A New Data Set Measuring Income Inequality”, World Bank Economic Review, 10(3): 565-91

Deininger, K. and Squire, L. (1998), "New Ways of Looking at Old Issues: Inequality and Growth", Journal of Development Economics, 57: 259-287

Dollar, D. and A. Kraay (2000), "Growth Is Good for the Poor", Macroeconomics and Growth Working Paper Number 2587, World Bank, Washington, D.C

Doussard, M. Peck, J., and Theodore, N. (2009), "After Deindustrialization: Uneven Growth and Economic Inequality in Postindustrial Chicago", Economic Geography, 85(2): 183-207

Easterly, W. (2005), "Globalization, Prosperity, and Poverty", in A. Harrison (Ed.), Globalization and Poverty. University of Chicago Press for NBER.

Feenstra, R. and G. Hanson (1997), "Foreign Direct Investment and Relative Wages: Evidence from Mexico's Maquila-doras”, Journal of International Economics, 42 (3): 371-393.

Fields, G. S. (1989), "Changes in Poverty and Inequality in Developing Countries", World Bank Research Observer, World Bank Group, 4(2): 167-85

Fosu, A. (2010), "Growth, Inequality and Poverty Reduction in Developing Countries: Recent Global Evidence", Background Paper for Global Development Outlook 2010, Shifting Wealth: Implications for Development, OECD Development Centre

Haq, M. and A. Sen (1990), "Human Development Concept", United Nations Development Program.

IMF (2010), "Pakistan: Poverty Reduction Strategy Paper", IMF Country Report no: 10. Washington D.C.

Jamal, H. (2003), "Poverty and Inequality during the Adjustment Decade: Empirical Findings from Household Surveys", The Pakistan Development Review, 42(2): 125-136

Jamal, H. (2004), "Does Inequality Matter for Poverty Reduction? Evidence from Pakistan's Poverty Trends", Research Report No. 58, Social Policy and Development Centre (SPDC)

Jha, R. (2000), "Reducing poverty and inequality in India: has liberalization helped? Available:http:// www.wider.unu.edu/research/1998-1999-3.1.publications.htm

Kanbur R. and L. Nora. (1999), "Why is Inequality Back on the Agenda?" Paper prepared for the Annual Bank Conference on Development Economics, World Bank, Washington, D.C.

Kuznets, S. (1955), "Economic Growth and Income Inequality". American Economic Review 45: 1-28

Lee, C. S. (2005), "International Migration, Deindustrialization and Union Decline in 16 Affluent OECD Countries 1962-1997”, Social Forces, Oxford University Press, 84 (1): 71-88

Lee, E., and Vivarelli, M. (2006b). The Social Impact of Globalization in Developing Countries. International Labor Review, 145(3), 167-184

Meschi E. and M. Vivarelli (2009), “Trade and Income Inequality in Developing Countries”,

World Development, 37(2): 287-302

Milanovic, B., and Squire, L. (2005), "Does Tariff Liberalization Increase Wage Inequality? Some Empirical Evidence", World Bank Policy Research Working Paper, No. 3571, World Bank, Washington, DC.

Pakistan, Govt. of (2013-14), “Economic Survey (Various Issues)”, Ministry of Finance.

Palma, G. (2008), "Deindustrialization, Premature Deindustrialization and the Dutch Disease", The New Palgrave: A Dictionary of Economics, $2^{\text {nd }}$ edition. Basingstoke: Palgrave Macmillan

Papanek, G. and O. Kyn (1986), "The Effect on Income Distribution of Development, the Growth Rate and Economic Strategy", Journal of Development Economics, 23(1): 55-65 
Planning Commission (2012), "Social Action Program", Report to the Pakistan Consortium. Islamabad. 2011-12.

PPAF (2013), "Poverty Perspectives", Pakistan Poverty Alleviation Fund. Islamabad.

Ravallion, M. (1997), "Can High Inequality Developing Countries Escape Absolute Poverty? World Bank Working Paper Number 1775, World Bank, Washington, D.C.

Ravallion, M. (2001), “Growth, Inequality and Poverty: Looking Beyond Averages”, World Development, 29(11): 1803-1815.

Ravallion, M. (2006), "Looking Beyond Averages in the Trade and Poverty Debate, World Development, 34(08): 1374-1392

Rodriguez, F. and Rodrick, D. (1999), “Trade Policy and Economic Growth; A Skepttic's Guide to the Criss-National Evidence, NBER Working Paper No.7081

Sachs J., J. Shatz, Alan Deardorff and Robert, H. (1994), "Trade and Jobs in U.S. Manufacturing", Brookings Papers on Economic Activity, 1: 1-84

Saeger, S. (1997), "Globalization and Deindustrialization: Myth and Reality in OECD", Weltwirtschaftliches Archives, 133 (4): 579-607

Shafaeddin (2005), "Trade Liberalization and Economic Reform in Developing Countries: Structural Change or deindustrialization?'Discussion Paper No. 179, United Nations Conference on Trade and Development

Sim, C. (1980), "Macroeconomics and Reality", Econometrica, 48 (1): 1-48

UNDP (1999), "Human Development Report", Oxford University Press. New York.

White H. and E. Anderson (2001), "Growth versus Distribution: Does the Pattern of Growth Matter?" Development Policy Review, 19 (3): 267-289

Wade R. H. (2004), "Is Globalization Reducing Poverty and Inequality? World Development, 32(4): 567-589

Wan, G., Lu M. and Z. Chen (2006), "Inequality-Growth Nexus in the Short and Long Runs: Empirical Evidence from China", Research Paper No. 92, World Institute for Development Economic Reserach

WIID (2012), 'World Income Inequality Database', World Institute for Development Economics Research. Finland.

Wood, A. (1994). North-South Trade, Employment, and Inequality: Changing Fortunes in a Skill-Driven World", Oxford: Clarendon Press

Yasmin B. and W. Qamar (2013), “The Role of Power Generation and Industrial Consumption Uncertainty in De-industrializing Pakistan", $29^{\text {th }}$ PSDE Annual General Meeting and Conference, Pakistan Institute of Development Economics, Islamabad

Zaidi, A. (2005), “Issues in Pakistan's Economy”, Oxford University Press. New York.

\section{NOTES}

${ }^{1}$ c.f., Meschi and Vivarelli (2009)

${ }^{2}$ The series for headcount is interpolated by Jamal (2004) by quadratic curve fitting on the actual observations by regressing log of poverty measure on time and time square variables. The gaps in data points are sourced by Pakistan, govt. of (2013-14).

${ }^{3}$ a) The GDP growth square is a traditional variable to add in inequality equation for checking Kuznet's hypothesis but not tested here because of its irrelevance to the other variables in the system.

b) The variable of human capital for inequality and poverty concerns was added but appeared as significant and hence was dropped from the final regression. 
${ }^{4}$ In the literature, reduced form and structural shocks are modeled as AB-model form (Amisano and Giannini (1997)) and our methodology follows that's steps for deriving empirical model.

${ }^{5}$ The estimation is done in Eviews 8.

${ }^{6}$ The Monte-Carlo findings are obtained by re-estimating the model taking 100 alternate orderings and computing arithmetic mean and standard errors of impulse response function. The results computed through monte-carlo are consistent with the findings of original model of IRF. The results are reported as Appendix for parsimony. 